\title{
Comparative study utilizing different post-breeding treatment regimens in cyclic Arabian mares
}

\author{
Khalid Mohammed Karam (iD, Ahmed Saed Alebady (D), Haitham O. Alhilfi(D) and Dhia Hussain Al-Delemi(D) \\ Department of Surgery and Obstetrics, College of Veterinary Medicine, University of Al-Qadisiyah, Al-Qadisiyah, Iraq. \\ Corresponding author: Khalid Mohammed Karam, e-mail: khalad.karam@qu.edu.iq \\ Co-authors: ASA: ahmed.abdulshaheed@qu.edu.iq, HOA: hathim.muhmmed@qu.edu.iq, \\ DHA: dheyaa.aldulaimi@qu.edu.iq \\ Received: 13-06-2021, Accepted: 29-09-2021, Published online: 10-11-2021
}

doi: www.doi.org/10.14202/vetworld.2021.2863-2868 How to cite this article: Karam KM, Alebady AS, Alhilfi HO, Al-Delemi DH (2021) Comparative study utilizing different post-breeding treatment regimens in cyclic Arabian mares, Veterinary World, 14(11): 2863-2868.

\begin{abstract}
Background and Aim: Post-breeding treatment is the most common practice in the reproductive management of mares. Oxytocin, uterine lavage, and intrauterine $(\mathrm{I} / \mathrm{U})$ antibiotic are usually used as prophylactic therapy. This study aimed to determine the most efficient prophylactic treatment regimen among six treatment protocols applied during natural breeding of cyclic Arabian mares.

Materials and Methods: The current study was conducted on cyclic Arabian mares that were subdivided into three age categories ( $n=968)$ : Category I ( $5-10$ years, $n=380)$, Category II (11-15 years, $n=361)$, and Category III $(\geq 16$ years, $n=227)$. Six prophylactic treatments were applied after $4 \mathrm{~h}$ of breeding. According to the treatment regimen, treated mares $(\mathrm{n}=483)$ were divided into six treatment groups: $\mathrm{A}(\mathrm{n}=80)$, treated with $\mathrm{I} / \mathrm{U}$ antibiotic $(1 \mathrm{~g}$ gentamicin); $\mathrm{B}(\mathrm{n}=81)$, I/U lavage (normal saline $500 \mathrm{~mL}) ; \mathrm{C}(\mathrm{n}=83)$, intramuscular $(\mathrm{I} / \mathrm{M})$ oxytocin (10 IU); D (n=82), I/U antibiotic and I/M oxytocin; $\mathrm{E}(\mathrm{n}=78), \mathrm{I} / \mathrm{U}$ lavage and I/M oxytocin; and $\mathrm{F}(\mathrm{n}=79), \mathrm{I} / \mathrm{U}$ lavage with $\mathrm{I} / \mathrm{U}$ antibiotic and $\mathrm{I} / \mathrm{M}$ oxytocin. Non-treated mares were classified as controls $(n=485)$. Ultrasonography was performed to monitor pregnant mares 30 and 60 days after mating, and mares were followed until foaling.
\end{abstract}

Results: Pregnancy and foaling results reveals that in age Category I, treatment with oxytocin alone or oxytocin with I/U lavage showed the highest pregnancy and foaling rates $(\mathrm{p}<0.01)$. In age Category II, the highest pregnancy and foaling rates were observed in lavage treatment $(p<0.01)$, whereas, in age Category III, the good pregnancy and foaling rates were monitored in treatment with oxytocin and $\mathrm{I} / \mathrm{U}$ lavage $(\mathrm{p}<0.01)$.

Conclusion: Treatment with systemic I/M oxytocin is ideal in early age group mares (5-10 years of age). However, irrespective of the age categories, all mares exhibited high pregnancy and foaling rates after treatment with systemic I/M oxytocin and I/U lavage with normal saline $(0.9 \%) 4 \mathrm{~h}$ post-breeding.

Keywords: endometritis, lavage, mare, oxytocin, persistent breeding-induced endometritis, post-breeding.

\section{Introduction}

Bacteria and excessive amounts of sperms normally invade the endometrium of mares during natural breeding or insemination [1]. As a normal physical process, fertile mares resolve this problem by pushing out bacteria and excessive spermatozoa from their endometrium through the vagina and vulva at $48 \mathrm{~h}$ after breeding. If mares fail in clearing the endometrium beyond the first $48 \mathrm{~h}$, a pathological condition called persistent breeding-induced endometritis (PBIE) develops [2]. PBIE, if untreated, may develop into infectious endometritis or endometrial fibrosis [3].

Infertility in mares due to endometritis is a major problem in equine breeds [4,5], and clinically, mares can be classified according to their resistance or

Copyright: Karam, et al. Open Access. This article is distributed under the terms of the Creative Commons Attribution 4.0 International License (http://creativecommons.org/licenses/by/4.0/), which permits unrestricted use, distribution, and reproduction in any medium, provided you give appropriate credit to the original author(s) and the source, provide a link to the Creative Commons license, and indicate if changes were made. The Creative Commons Public Domain Dedication waiver (http://creativecommons.org/ publicdomain/zero/1.0/) applies to the data made available in this article, unless otherwise stated. susceptibility to develop PBIE [6,7]. Mares who fail to eliminate inflammation and develop PBIE are mainly older in age [8] or may have problems in vulvar shape or have pendulous uterus [9]. Approximately $10-15 \%$ of mares are susceptible to the development of PBIE [10].

Probable PBIE cases are diagnosed clinically by ultrasonography if there is more than $2 \mathrm{~cm}$ of uterine fluid in the uterine lumen during estrus [11] or within $36 \mathrm{~h}$ after breeding [4]. Treatment after breeding is crucial in decreasing the risk of endometritis and increasing the conception rates [12-14].

There are several treatment protocols used in the field to reduce endometrial inflammation and increase conception rates. This study aimed to compare six treatment protocols used during natural breeding of cyclic Arabian mares with different ages to detect the credible efficient protocol.

\section{Materials and Methods}

\section{Ethical approval}

This study followed the guidelines of the Ethics Committee and current legislation on research and ethical approval of the Faculty of Veterinary Medicine 
(approval no. VCU-026-2-14), Cairo University, Egypt.

\section{Study period and location}

The study was conducted from May 2012 to January 2015. The study was conducted at Animal Production Section of Countryside Experimental Station at the Research Institute and Private clinics in Cairo Governorate, Egypt.

\section{Animal}

The current study was conducted on healthy cyclic Arabian mares $(n=968)$ with body score condition of 4 and 5 according to Henneke et al.'s [15] scoring. Mares were managed in stables in the countryside of Cairo, Egypt, and fed with supplemented balanced ration and checked from May 2012 to January 2015 by veterinary visits. Mares were categorized into three age groups: Category I ( $5-10$ years, $n=380)$, Category II ( $11-15$ years, $n=361$ ), and Category III ( $\geq 16$ years, $n=227$ ).

\section{Post-breeding treatment}

The current study was conducted on cyclic Arabian mares that were subdivided into three age categories $(n=968)$ : Category I $(5-10$ years, $n=380)$, Category II $(11-15$ years, $n=361)$, and Category III $(\geq 16$ years, $n=227)$, treated mares $(n=483)$ and were divided into six groups: A $(\mathrm{n}=80)$, treated with intrauterine $(\mathrm{I} / \mathrm{U})$ antibiotic ( $1 \mathrm{~g}$ of gentamicin); $\mathrm{B}(\mathrm{n}=81)$, $\mathrm{I} / \mathrm{U}$ lavage (normal saline $500 \mathrm{~mL}) ; \mathrm{C}(\mathrm{n}=83)$, intramuscular (I/M) oxytocin (10 IU); D (n=82), I/U antibiotic and $\mathrm{I} / \mathrm{M}$ oxytocin; $\mathrm{E}(\mathrm{n}=78), \mathrm{I} / \mathrm{U}$ lavage and $\mathrm{I} / \mathrm{M}$ oxytocin; and $\mathrm{F}(\mathrm{n}=79), \mathrm{I} / \mathrm{U}$ lavage with $\mathrm{I} / \mathrm{U}$ antibiotic and $\mathrm{I} / \mathrm{M}$ oxytocin. Non-treated mares were classified as controls $(n=485)$. All mares were inseminated by natural mating, and all treatments were applied $4 \mathrm{~h}$ post-breeding.

\section{Ultrasound examination}

Pregnancy was confirmed through ultrasonography using B-mode ultrasound attached to a linear probe and at $10 \mathrm{MHz}$ frequency (eSaote, MyLab ${ }^{\circledR}$, Genoa, Italy). Pregnancy was evaluated 30 and 60 days after mating by monitoring embryonic vesicle and embryo, and pregnant mares were followed until foaling.

\section{Statistical analysis}

The entire statistical analysis was conducted using Statistical Package for the Social Sciences version 23.0 (IBM Corp., New York, USA) $\mathrm{p}<0.05$ and 0.01 were used to determine the level of significance. Data were first checked for normal distribution; then, the difference between the treated groups within different age categories was analyzed using Chi-square method.

\section{Results}

All treated cases $(n=483)$ were compared to those that did not receive treatment (control group $n=485$ ).

\section{Day 30 of pregnancy}

Pregnancy 30 days after breeding in accordance with the age categories and treatment protocol is presented in Table-1 and Figure-1. In Category I (5-10 years), pregnancy assessment revealed that treatments $\mathrm{C}$ and $\mathrm{E}$ had the highest pregnancy rate, reaching $100 \%(\mathrm{p}<0.01)$, while it was $93.47 \%, 92.10 \%$, and $90.90 \%$ for treatments $\mathrm{D}, \mathrm{B}$, and F, respectively $(p<0.05)$. Treatment A showed no significant difference $(81.48 \%$ vs. $77.84 \%)$.

The results of pregnancy assessment in Category II (11-15 years) showed that pregnancy rates for treatments B, F, D, and E were $100 \%, 96 \%, 95.23 \%$, and $93.93 \%$, respectively $(p<0.01)$, while those for treatments $\mathrm{C}$ and $\mathrm{A}$ were $89.74 \%$ and $88.88 \%$, respectively $(\mathrm{p}<0.05)$, compared to controls $(75.25 \%)$.

The pregnancy assessment revealed that in Category III ( $\geq 16$ years), treatment $\mathrm{E}$ had the highest pregnancy rate $(71.42 \%)(\mathrm{p}<0.01)$, whereas, in treatments $\mathrm{C}, \mathrm{B}, \mathrm{A}$, and $\mathrm{D}$, the pregnancy rates were $69.23 \%, 68.75 \%, 66.66 \%$, and $66.66 \%$, respectively $(\mathrm{p}<0.05)$. However, treatment $\mathrm{F}$ showed no difference $(58.82 \%$ vs. $55.85 \%)$.

\section{Day 60 pregnancy}

On day 60 post-breeding, the pregnancy assessment was performed, and the results are shown

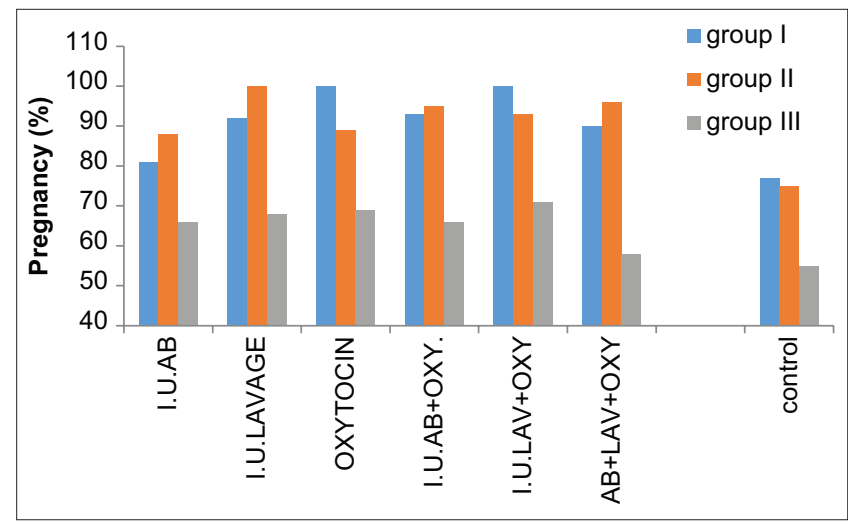

Figure-1: Histogram shows pregnancy 30 days post-breeding in different treatment regimens and in different age category groups.

Table-1: Percentage of pregnancy 30 days post-breeding in different treatment regimens and in different age category groups.

\begin{tabular}{|c|c|c|c|c|c|c|c|}
\hline \multirow[t]{2}{*}{ Age categories } & \multicolumn{7}{|c|}{ Treatments } \\
\hline & $A(n=80)$ & B $(n=81)$ & $C(n=83)$ & $D(n=82)$ & $E(n=78)$ & $F(n=79)$ & Control $(n=485)$ \\
\hline I & c81.48\% & в92.1\% & ${ }^{A} 100 \%$ & в93.47\% & ${ }^{A} 100 \%$ & в90.9\% & c77.84\% \\
\hline II & в88.88\% & ${ }^{A} 100 \%$ & в89.74\% & A95.23\% & A93.93\% & A96\% & c75.25\% \\
\hline III & в66.66\% & в68.75\% & в69.23\% & в66.66\% & A71.42\% & с58.82\% & с55.85\% \\
\hline
\end{tabular}

A refers to significant difference $(p<0.01)$ within rows, B refers to significant difference $(p<0.05)$ within rows, C refers to no significant difference within rows 
in Table-2 and Figure-2. The pregnancy assessment in Category I (5-10 years) showed that treatments $\mathrm{C}$ and E had the highest pregnancy rates, reaching $100 \%$ and $96.42 \%$, respectively $(p>0.01)$, whereas pregnancy rates in treatments $\mathrm{D}, \mathrm{F}$, and $\mathrm{B}$ were $91.30 \%, 87.87 \%$, and $86.84 \%$, respectively $(\mathrm{p}>0.05)$. However, the pregnancy rate in treatment $\mathrm{A}$ was not different (77.77\% vs. $76.62 \%)$.

The pregnancy assessment in Category II (11-15 years) revealed that pregnancy rates in treatments B, F, D, and E were $100 \%, 96 \%, 95.23 \%$, and $93.54 \%$, respectively $(\mathrm{p}<0.01)$. Pregnancy rates in treatments $\mathrm{C}$ and $A$ were $84.61 \%$ and $83.33 \%$, respectively $(\mathrm{p}<0.05)$.

The pregnancy assessment in Category III ( $\geq 16$ years) showed that treatment $\mathrm{B}$ has the highest results, reaching $62.25 \%(\mathrm{p}<0.01)$, whereas rates in treatments $\mathrm{A}$ and $\mathrm{E}$ were $60 \%$ and $57.14 \%$, respectively $(p<0.05)$. However, treatments D, C, and F did not show a significant difference in pregnancy rates compared to controls (55.55\%, $53.84 \%$, and $41.17 \%$ vs. $48.44 \%)$.

\section{Foaling day}

All pregnant mares were followed until foaling; the foaling percentage is shown in Table-3

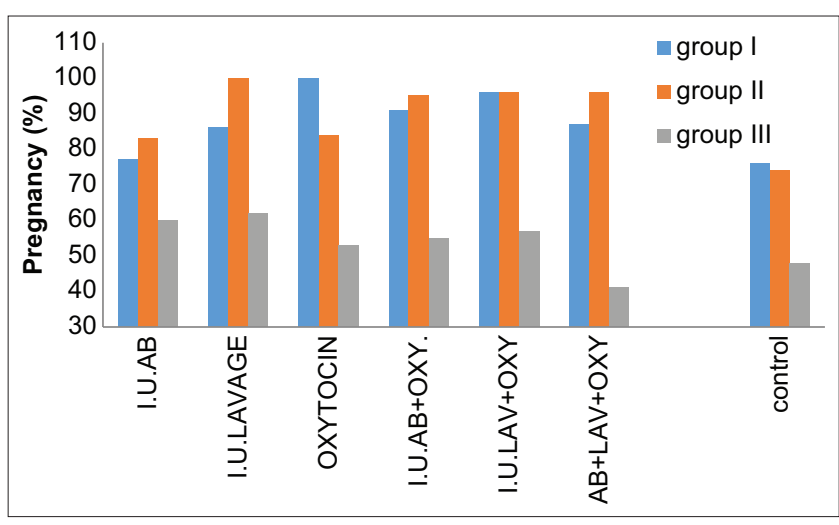

Figure-2: Histogram shows pregnancy 60 days post-breeding in different treatment regimens and in different age category groups. and Figure-3. In Category I, the highest foaling percentages were noted in treatments C and E $(96.87 \%$ and $96.42 \%$, respectively) ( $>0.01$ ), and percentages in treatments $\mathrm{F}$, D, and $\mathrm{B}$ were $87.87 \%, 86.95 \%$, and $84.21 \%$, respectively $(\mathrm{p}>0.05)$. However, treatment A showed no significant difference $(74.07 \%$ vs. $75.56 \%)$.

In Category II, the highest foaling rates were observed in treatments B, F, and $\mathrm{E}(100 \%, 96 \%$, and $93.54 \%$, respectively, $p>0.01)$ and treatments D $(90.47 \%)$ and C (84.61) ( $>0.05)$, whereas treatment A showed no significant difference $(77.77 \%$ vs. $73.23 \%$ ).

In Category III, the rates in treatments E, B, and A were $57.14 \%, 56.25 \%$, and $53.33 \%$, respectively ( $>0.05$ ), whereas treatments D, F, and C did not show a significant difference with the controls $(44.44 \%$, $41.17 \%$, and $38.46 \%$ vs. $44.14 \%$ ).

\section{Discussion}

Some mares are susceptible to develop endometritis after artificial insemination or natural mating because of considerable disturbances in mares' defense mechanisms or due to anatomical malformations. However, in certain mares, the defense system is inefficient, and mares become vulnerable to endometritis before spontaneous mating or artificial insemination. Moreover, the uterine fluid has the potential to function as a culture medium for bacteria that may enter the uterus and reduce spermatozoa and subsequently embryo survival [16,17]. Endometritis after insemination or mating is a common problem that usually causes infertility or early embryonic death $[17,18]$. Persistent endometrial inflammation may develop into chronic infectious endometritis, which is observed in $25-60 \%$ of barren mares [19,20], due to the presence of many microorganisms in the uterus, mostly Escherichia coli and Streptococcus

Table-2: Percentage of pregnancy 60 days post-breeding in different treatment regimens and in different age category groups.

\begin{tabular}{|c|c|c|c|c|c|c|c|}
\hline \multirow[t]{2}{*}{ Age categories } & \multicolumn{7}{|c|}{ Treatment } \\
\hline & $A(n=80)$ & B $(n=81)$ & $C(n=83)$ & $D(n=82)$ & $E(n=78)$ & $F(n=79)$ & Control $(n=485)$ \\
\hline I & c77.77\% & в86.84\% & $\mathrm{A} 100 \%$ & в91.3\% & A96.42\% & в87.87\% & c76.62\% \\
\hline II & ${ }^{\mathrm{B}} 83.33 \%$ & A $100 \%$ & в84.61\% & A95.23\% & A93.54\% & A96\% & c74.43\% \\
\hline III & ${ }^{\mathrm{B}} 60 \%$ & ${ }^{A} 62.25 \%$ & '53.84\% & '55.55\% & B $57.14 \%$ & ${ }^{\circ} 41.17 \%$ & ' $48.44 \%$ \\
\hline
\end{tabular}

A refers to significant difference $(p<0.01)$ within rows, B refers to significant difference $(p<0.05)$ within rows, C refers to no significant difference within rows

Table-3: Percentage of foaling in different treatment regimens and in different age category groups.

\begin{tabular}{|c|c|c|c|c|c|c|c|}
\hline \multirow[t]{2}{*}{ Age categories } & \multicolumn{7}{|c|}{ Treatment } \\
\hline & $A(n=80)$ & $B(n=81)$ & $C(n=83)$ & $D(n=82)$ & $E(n=78)$ & $F(n=79)$ & Control $(n=485)$ \\
\hline I & c74.07\% & в84.21\% & A96.87\% & в86.95\% & A96.42\% & в87.87\% & c75.56\% \\
\hline II & c77.77\% & A $100 \%$ & в84.61\% & в90.47\% & A93.54\% & A96\% & c73.23\% \\
\hline III & в53.33\% & В56.25\% & c38.46\% & c44.44\% & В57.14\% & c41.17\% & c44.14\% \\
\hline
\end{tabular}

A refers to significant difference $(p<0.01)$ within rows, B refers to significant difference $(p<0.05)$ within rows, C refers to no significant difference within rows 


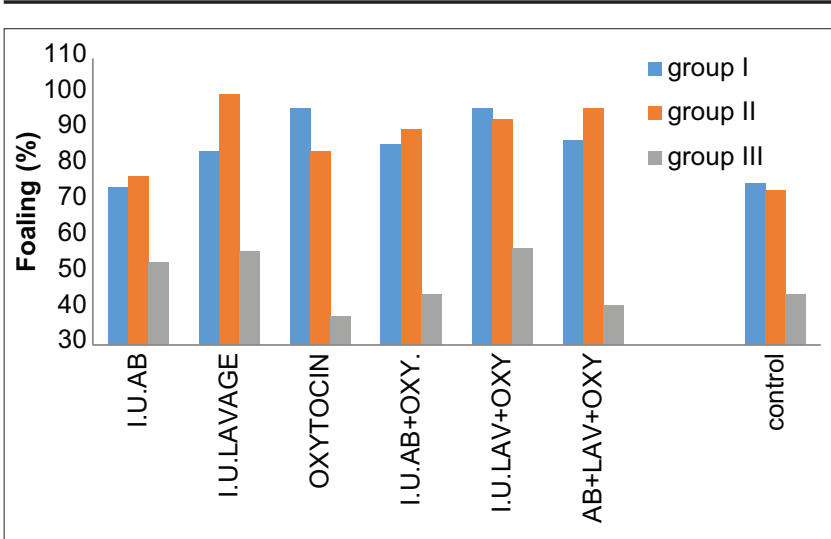

Figure-3: Histogram shows foaling in different treatment regimens and in different age category groups.

zooepidemicus [4,16,21]. Several treatments, traditional and nontraditional, were used after mating to reduce inflammation and maintain fertility. Traditional treatments, such as uterine lavage, injection of oxytocin, and I/U antibiotic administration, were used after mating in many clinical programs to maintain mares' fertility [13,14,17,20-22].

The benefits of oxytocin injection after breeding are to stimulate the contractions of uterine muscles to eliminate excessive sperms and bacteria that enter the uterus during natural mating or insemination [23,24]. Oxytocin is widely used during estrus or foal heat because of its contractile action on the myometrium that accelerates uterine involution [25] and mucosal degeneration [26]. The effective oxytocin dose that produces myometrial contractility and enhances mares' fertility is 10-20 IU $[27,28]$. Oxytocin can be injected after $4 \mathrm{~h}$ of breeding because sperms complete their transport to the oviduct around that time; thus, treatment with oxytocin and uterine lavage can be performed after $4 \mathrm{~h}$ post-breeding without any interference with sperm movement and mare fertility or pregnancy rates $[29,30]$.

Uterine lavage by normal saline after breeding has been used repeatedly in farms because of its ability to increase the tone of uterine muscles [31] and its efficiency to clear the uterine lumen from microorganisms, dead sperms, inflammatory cells, and debris, which are known to be possible reasons for early embryonic death $[32,33]$. Uterine lavage can reintroduce active viable neutrophils that can induce microbial degradation in stagnant inflammations [22].

Gentamicin is an aminoglycoside bactericidal and broad-spectrum antibiotic that is used repeatedly to treat bacterial endometrial infections in mares [34]. Its mechanism of action involves inhibition of bacterial protein synthesis by binding to $30 \mathrm{~S}$ subunit of bacterial ribosomes; therefore, gentamicin is indicated as one of the broad-spectrum antibiotics for the treatment of acute serious infections, such as those caused by Gram-negative bacteria [35]. In the current study, administration of a single dose of gentamicin as I/U antibiotic has little effect on pregnancy rates in mares compared with other prophylactic regimens. This is similar to the findings that were reported in a previous study [36]. Moreover, they assume that the I/U route may irritate the endometrium and might lead to inconsistent tissue penetration, which facilitates the development of antimicrobial resistance. Administration of antibiotic with uterine lavage in combination with oxytocin injection was reported as a good protocol to increase mares' fertility $[12,13]$.

Our results revealed that administration of oxytocin alone resulted in significant foaling rate in age Categories I and II but not in Category III. It might be possible that older age mares with multiple foaling histories respond less to oxytocin than younger mares; furthermore, the size of the uterus in these mares might not permit the complete evacuation of semen and debris after mating after treatment with oxytocin only.

According to our results, it seems that $\mathrm{I} / \mathrm{U}$ lavage by normal saline in combination with oxytocin injection is a common best protocol in all three age groups and showed the highest percentages of pregnancy in all groups with significant differences compared with the controls of the same ages; therefore, we recommend using this protocol after $4 \mathrm{~h}$ of every stallion mount in Arabian mare breeding programs.

\section{Conclusion}

To reduce possible post-breeding uterine inflammation cases in cyclic Arabian mares, six treatment protocols were applied on mares at different ages after natural breeding. Uterine lavage + oxytocin injection is the best treatment protocol for all ages of cycling Arabian mares that reduce uterine inflammation after natural mating and increase pregnancy and foaling rates.

\section{Authors' Contributions}

KMK, ASA, HOA, and DHA: Involved in the conception of the research idea and methodology design, performed the data analysis and interpretation, and prepared the manuscript for publication. KMK and DHA: Participated in the design of the methodology and involved in fieldwork. KMK: Project supervision, study design, and data interpretation. ASA and HOA: Participated in the manuscript preparation, data analysis, and contributed their scientific advice during the work and revision. All authors read and approved the final manuscript.

\section{Acknowledgments}

The study was funded by University of Al-Qadisiyah-Grant Iraqi Individuals, Al-Diwaniyah, Iraq (Grant number 1089 in 2014). We would like to thank all our colleagues and all the workers in the 
institute for their assistance in the completion of this study.

\section{Competing Interests} interests.

The authors declare that they have no competing

\section{Publisher's Note}

Veterinary World remains neutral with regard to jurisdictional claims in published institutional affiliation.

\section{References}

1. Troedsson, M.H., Liu, I.K. and Crabo, B. (1998) Sperm transport and survival in the mare. Theriogenology, 49(5): 905-915.

2. Christoffersson, M. and Troedsson, M. (2017) Inflammation and fertility in the mare. Reprod. Domest. Anim., 52(3): 14-20.

3. Morris, L.H.A., McCue, P.M. and Aurich, C. (2020) Equine endometritis: A review of challenges and new approaches. Reproduction, 160(5): R95-R110.

4. Leblanc, M.M. (2010) Advances in the diagnosis and treatment of chronic infectious and post-mating induced endometritis in the mare. Reprod. Domest. Anim. 45(2): 21-27.

5. Troedsson, M.H.T. and Woodward, E.M. (2016) Our current understanding of the pathophysiology of equine endometritis with an emphasis on breeding induced endometritis. Reprod. Biol., 16(1): 8-12.

6. Leblanc, M.M., Neuwirth, L., Asbury, A.C., Tran, T., Mauragis, D. and Klapstein, E. (1994) Scintigraphic measurements of uterine clearance in normal mares and mares with recurrent endometritis. Equine Vet. J., 26(2): 109-113.

7. Troedsson, M.H.T., Desvousges, A., Macpherson, M.L. and Pozor, M.P. (1994) persistent breeding induced endometritis. Pferdeheilkunde, 24(1): 56-60.

8. Woodward, E.M., Christoffersen, M., Campos, J., Squiers, E.L. and Troedsson, M.H.T. (2012) Susceptibility to persistent breeding induced endometritis in the mare: Relationship to endometrial biopsy score and age, and variations between seasons. Theriogenology, 78(3): 495-510.

9. Scoggin, C.F. (2015) Not just a number: Effect of age on fertility, pregnancy and offspring vigour in Thoroughbred brood-mares. Reprod. Fertil. Dev., 27(6): 872-879.

10. Zent, W.W., Troedsson, M.H.T. and Zue, J.L. (1998) Post-breeding Uterine Fluid Accumulation in a Normal Population of Thoughrobred Mares. A Field Study. In Proceeding of the $40^{\text {th }}$ Annual Convention of the American Association of Equine Practitioners, Baltimore, MD, USA. p64-65.

11. Brinsko, S.P., Rigby, S., Varner, D.D. and Blanchard, T.L. (2003) A Practical Method for Recognizing Mares Susceptible to Post-breeding Endometritis. Proceeding of the American Association of Equine Practitioners, Las Vegas, NV, USA. p363-365.

12. Azawi, O.J. (2008) Effect on fertility on human chorionic gonadotropin and uterine lavage with oxytocin performed after mating in Arabian barren mares. Anim. Reprod. Sci., 106(3-4): 345-361.

13. Canisso, I.F., Segabinazzi, L.G.T. and Fedorka, C.E. (2020) Persistent breeding induced endometritis in mares-a multifaceted challenge: From clinical aspects to immunopathogenesis and pathobiology. Int. J. Mol. Sci., 21(4): 1432.

14. Kundak, M. and Kilicarslan M.R. (2018) The effect of uterine lavage and oxytocin administration before and after breeding on fertility in mares in the first postpartum breeding estrus. Acta Vet. Eur., 44(3): 112-116.

15. Henneke, D.R., Potter, G.D., Kreider, J.L. and Yeates, B.F.
(1983) Relationship between condition score, physical measurements and body fat percentage in mares. Equine Vet. J., 15(4): 371-372.

16. Canisso, I.F., Stewart, J. and Coutinho Da Silva, M.A. (2016) Endometritis: Managing persistent post-breeding endometritis. Vet. Clin. North Am. Equine Pract., 32(3): 465-480.

17. Nielsen, J.M., Troedsson, M.H., Pedersen, M.R., Bojesen, A.M., Lehen-Jensen, H. and Zent, W.W. (2010) Diagnosis of endometritis in the mare based on bacteriological and cytological examinations of the endometrium: Comparison of results obtained by swabs and biopsies. $J$. Equine Vet. Sci., 30(1): 27-30.

18. Leblanc, M.M. and Causey, R.C. (2009) Clinical and subclinical endometritis in the mare: both threats to fertility. Reprod. Domest. Anim., 44(3): 10-22.

19. Huber, D., Amsler, E., Vidondo, B., Kaeser, R., Wespi, B., Sieme, H. and Burger, D. (2019) Increase of pregnancy rate after multiple periovulatory inseminations in mares. Tierarztl Prax Ausg G Grosstiere Nutztiere, 47(1): $18-24$.

20. Mattos, R., Castilho, L.F.F., Malschitzky, E., Neves, A.P., Keller, I.M., Gregory, R.M. and Mattos, R.C. (1997) Uterine lavage with saline in mares as treatment for endometritis. Pferdeheilkunde, 13(5): 521-524.

21. Scoggin, C.F. (2016) Endometritis: Nontraditional therapies. Vet. Clin. North Am. Equine Pract., 32(3): 499-511.

22. Cadario, M.E., Thatcher, M.J.D. and Leblanc, M.M. (1995) Relationship between prostaglandin and uterine clearance of radiocolloid in the mare. Biol. Reprod., 52(1): 495-500.

23. Rasch, K., Schoon, H.A., Sieme, H. and Klug, E. (1996) Histomorphological endometrial status and influence of oxytocin on the uterine drainage and pregnancy rate in mares. Equine Vet. J., 28(6): 455-460.

24. Nikolakopoulos, E. and Watson, E.D. (1999) Uterine contractility is necessary for the clearance of intrauterine fluid but not bacteria after bacterial infusion in the mare. Theriogenology, 52(3): 413-423.

25. Katila, T. and Reilas, T. (2001) The postpartum mare. Pferdeheilkunde, 17(6): 623-626.

26. Cadario, M.E., Merritt, A.M., Archbald, L.F., Thatcher, W.W. and Leblanc, M.M. (1999) Changes in intrauterine pressure after oxytocin administration in reproductively normal mares and in those with a delay in uterine clearance. Theriogenology, 51(5): 1017-1025.

27. Maddil, S., Troedsson, M.H.T., Santschi, E.M. and Malone, E.D. (2002) Dose-response effect of intramuscular oxytocin treatment on myometrial contraction of reproductively normal mares during estrus. Theriogenology, 58(2): 479-481.

28. Brinsko, S.P., Varner, D.D. and Blanchard, T.L. (1991) The effect of uterine lavage performed 4 hours post insemination on pregnancy rate in mares. Theriogenology, 35(2): 1111-1119.

29. Fiala, S.M., Pimentel, C.A., Mattos, A.L., Gregory, R.M. and Mattos, R.C. (2007) Effect of sperm numbers and concentration on sperm transport and uterine inflammatory response in the mare. Theriogenology, 67(3): 556-562.

30. Brinsko, S. P. (2001) How to perform uterine lavage: indications and practical techniques. In Proceedings of the $47^{\text {th }}$ AAEP Annual Convention: 24-28 November 2001 (pp. 407-411).

31. Vanderwall, D.K. and Woods, G.L. (2003) Effect on fertility of uterine lavage performed immediately prior to insemination in mares. J. Am. Vet. Med. Assoc., 222(8): 1108-1110.

32. Knutti, B., Pycock, J.F., Weijden, G.C. and Kupfer, U. (2010) The influence of early post-breeding uterine lavage on pregnancy rate in mares with intrauterine fluid accumulations after breeding. Equine Vet. Educ., 12(10): 267-270.

33. Walter, J., Neuberg, K.P., Failing, K. and Wehrend, A. (2012) Cytological diagnosis of endometritis in the mare: Investigations of sampling techniques and relation to 
bacteriological results. Am. Rep. Sci., 132(3-4): 178-186.

34. Dascanio, J.J. (2011) How and When to Treat Endometritis with Systemic or Local Antibiotics. In Proceedings of the 57 American Association of Equine Practitioners, San Antonio, TX, USA. p57.

35. Krause, K.M., Serio, A.W., Kane, T.R. and Connolly, L.E. (2016) Aminoglycosides: An overview. Cold Spring Harb.
Perspect. Med., 6(6): a027029.

36. Rose, B.V., Firth, M., Morris, B., Roach, J.M., Wathes, D.C., Verheyen, K.L.P. and de Mestre, A.M. (2018) Descriptive study of current therapeutic practices, clinical reproductive findings and incidence of pregnancy loss in intensively managed thoroughbred mares. Anim. Reprod. Sci., 188(1): $74-84$.

$* * * * * * * *$ 